\title{
Structure of New Cyclic Depsipeptides, Bu-2841-08 and -10
}

\author{
Toshio FuKal, Jun Kuroda ${ }^{\dagger}$, Masataka Konishi \\ and TARO NOMURA* \\ Faculty of Pharmaceutical Sciences, Toho University,
} 2-2-1 Miyama, Funabashi, Chiba 274, Japan

NOBUAKI NARUSE

Tsukuba Research Laboratories, Eisai Co., Ltd., 5-1-3 Tokodai, Tsukuba, Inashiki 300-26, Japan

\section{RYUICHI ISOBE}

Faculty of Pharmaceutical Sciences, Kyushu University, 3-1-1 Maidashi, Higashi-ku, Fukuoka 812, Japan

(Received for publication May 11, 1995)

\begin{abstract}
The structures of new antibiotics, Bu-2841-08 and -10, have been determined. They are cyclic depsipeptides and the sequence of amino acid residues was established by mass spectral analysis of the hydrolyzed linear peptide and NMR spectral analysis of the parent cyclic peptides.
\end{abstract}

\section{Results and Discussion}

An unidentified Gram-negative bacteria, K-341-B7, was found to produce a new antibiotic complex, $\mathrm{Bu}-2841$. The antibiotic complex was isolated from whole broth by chromatography on silica gel and Sephadex LH-20. HPLC analysis showed that the complex was composed of at least ten components. Four components, Bu-2841$02,-04,-08$, and -10 , were isolated from the complex and purified by reversed phase HPLC. Chemical characterization of the components indicated that they were peptides. Although the four antibiotics isolated here behaved as a single entity under all conditions tested for HPLC, their NMR spectra indicated that $\mathrm{Bu}-2840-08$ and -10 were a mixture of three or four homologous components, and the others were mixtures of more than four peptides. In this paper, we will describe the isolation, structures and biological properties of $\mathrm{Bu}-2841-08$ and -10 .

\section{Isolation and Purification}

A flow diagram for the isolation procedure is given in Fig. 1. Activities against Staphylococcus aureus FDA 209P and Bacillus subtilis (PCI 219 (medium pHs were 6 and 8), H17, and M45) were employed to monitor the isolation of antibiotic $\mathrm{Bu}-2841$ complex. The whole broth (39 liters) was extracted with $n$-butanol and the extract was concentrated in vacuo. It was then diluted with ethyl acetate until a precipitate appeared. The precipitate was extracted three times with aqueous acetonitrile. The acetonitrile was evaporated and then lyophilized to yield

Fig. 1. Isolation procedure of Bu-2841-02, $-04,-08$, and -10 .

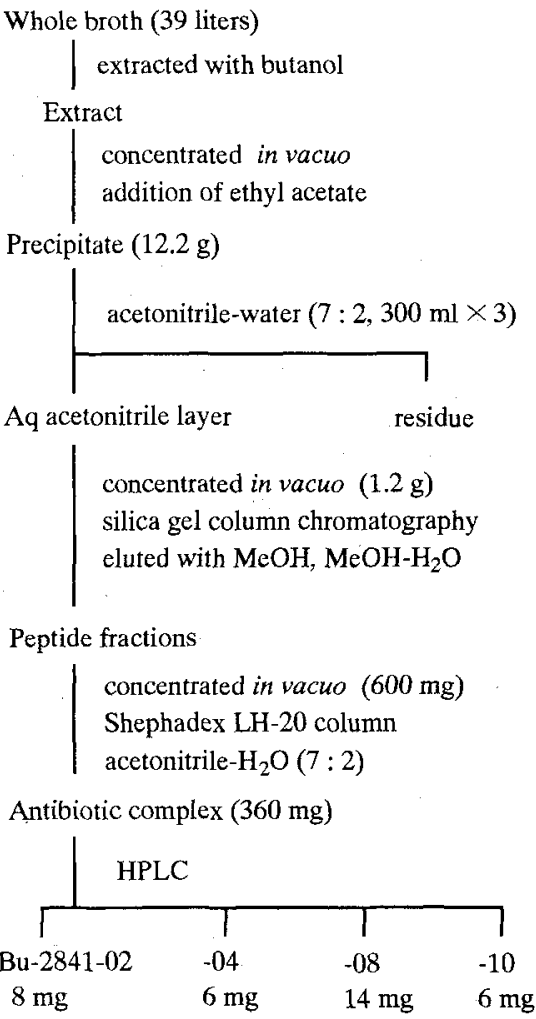

\begin{tabular}{llll}
\hline & & 1 & \\
$\mathrm{Bu}-2841-02$ & -04 & -08 & -10 \\
$8 \mathrm{mg}$ & $6 \mathrm{mg}$ & $14 \mathrm{mg}$ & $6 \mathrm{mg}$
\end{tabular}

† Present address: Pharmaceutical Technology Lab., Yamanouch Pharmaceutical Co., Ltd., 180 Ozumi, Yaizu, Sizuoka 425, Japan 
Table 1. Consistent amino acids ${ }^{a}$ and optical rotations of Bu-2841 complex.

\begin{tabular}{|c|c|c|}
\hline Consistent amino acid & {$[\alpha]_{\mathrm{D}}(5 \mathrm{~N} \mathrm{HCl})$} & Assigned chirality \\
\hline Asp (3.2) & $-5^{\circ} \quad\left(\begin{array}{ll}c & 1.0\end{array}\right)$ & $2 \mathrm{D}+1 \mathrm{~L}$ \\
\hline Thr $\quad(1.0)$ & $-12^{\circ} \quad\left(\begin{array}{ll}c & 0.4\end{array}\right)$ & $\mathrm{L}$ \\
\hline Ser $(1.0)$ & $-10^{\circ} \quad\left(\begin{array}{cc}c & 0.5\end{array}\right)$ & $\mathrm{D}$ \\
\hline Gly (2.2) & & \\
\hline Phe (1.2) & $-5^{\circ} \quad\left(\begin{array}{cc}c & 1.0\end{array}\right)$ & $\mathrm{L}$ \\
\hline $\mathrm{Dab}^{\mathrm{b}}(2.1)$ & $0^{\circ} \quad\left(\begin{array}{cc}c & 1.5)\end{array}\right.$ & $\mathrm{D}+\mathrm{L}$ \\
\hline Ile $(0.9)$ & $+35^{\circ} \quad(c 1.0)$ & $\mathrm{L}$ \\
\hline Leu $(0.3)$ & & \\
\hline Val $(0.2)$ & $+19^{\circ}(c \quad 0.3)$ & $\mathrm{L}$ \\
\hline
\end{tabular}

${ }^{\mathrm{a}}$ The molecular ratios. ${ }^{\mathrm{b}}$ 2,4-diaminobutyric acid.

a residue. The residue was dissolved in a small amount of methanol and subjected to a silica gel column subsequently eluted with methanol and aqueous methanol. Active fractions were further purified by a Sephadex LH-20 column eluted with aqueous acetonitrile. The antibiotic complex was obtained as a colorless powder. An analytical HPLC chromatogram of the complex showed that it consisted of at least ten components designated as $\mathrm{Bu}-2841-01 \sim \mathrm{Bu}-2841-10$. Amino acid analysis of the complex after hydrolysis with $6 \mathrm{~N} \mathrm{HCl}$ and optical rotations of these amino acids (Table 1) suggested that the main peptides contained D-aspartic acid (2 eq.), L-aspartic acid (1 eq.), L-threonine (1 eq.), D-serine (1 eq.), glycine (2 eq.), L-isoleucine (1 eq.), Lphenylalanine (1 eq.), D-2,4-diaminobutyric acid (1 eq.), and L-2,4-diaminobutyric acid (1 eq. $)^{1)}$. UV spectrum of the complex also indicated the presence of a tryptophan residue in the antibiotics (UV $\lambda_{\max }: 205,240$ (sh), 274, 281, $290 \mathrm{~nm}$ ). GC-MS of methyl esters of the fatty acids which were obtained by hydrolysis of the antibiotic complex suggested that the acyl group consisted of more than ten $\beta$-hydroxylfatty acids $\left(\mathrm{C}_{8} \sim \mathrm{C}_{12}\right)$ and normal fatty acids. In order to isolate each component, the complex was subjected to a reversed phase HPLC under the condition as follows: Packing; Capcell Pak $\mathrm{C}_{18}$ (Shiseido, $10 \times 250 \mathrm{~mm}$ ), mobile phase; isopropanolacetonitrile- $0.1 \%$ trifluoroacetic acid $(3: 1: 6)$, flow rate; $1.2 \mathrm{ml} /$ minute, detection; UV at $230 \mathrm{~nm}$. By this procedure, the four components, Bu-2841-02 (8 mg), -04 $(6 \mathrm{mg}),-08(14 \mathrm{mg})$, and $-10(6 \mathrm{mg})$, were isolated. The results of FAB-MS and amino acid analyses of these antibiotics are shown in Table 2.

Structures of Bu-2841-08 (1) and -10 (2)

Amino acid analysis of Bu-2841-08 (1) gave a com-

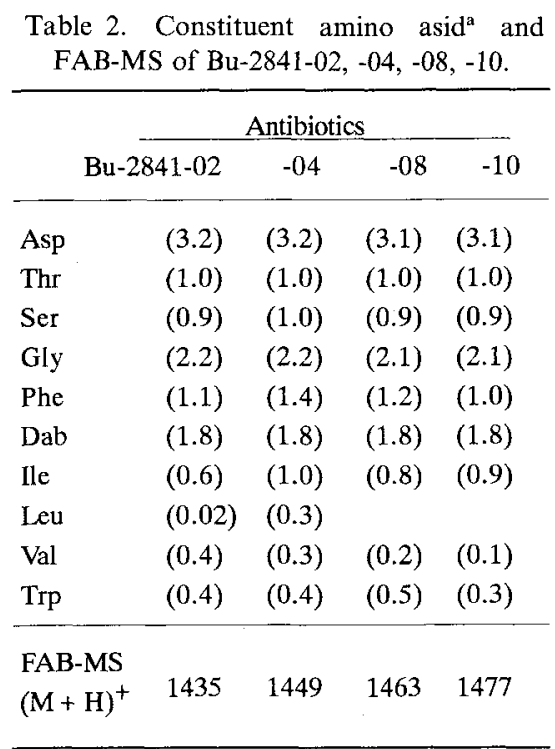

${ }^{\mathrm{a}}$ The molecular ratios.

position: aspartic acid ( 3 eq.), serine ( 1 eq.), glycine ( 2 eq.), phenylalanine ( 1 eq.), 2,4-diaminobutiric acid ( 2 eq.), tryptophan (1 eq.), threonine (1 eq.), isoleucine ( 0.8 eq.), and valine ( 0.2 eq.). High resolution FAB-MS of 1 gave a MW, $m / z 1463.7170(\mathrm{M}+\mathrm{H})^{+}$, which fits the molecular formula, $\mathrm{C}_{67} \mathrm{H}_{98} \mathrm{O}_{21} \mathrm{~N}_{16}$. These data indicated that the peptide contains one asparagine and two aspartic acids and consists of two kinds of cyclic peptide moieties having isoleucine $\left(\mathrm{C}_{57} \mathrm{H}_{79} \mathrm{O}_{19} \mathrm{~N}_{16}\right)$ and valine $\left(\mathrm{C}_{56} \mathrm{H}_{77} \mathrm{O}_{19} \mathrm{~N}_{16}\right)$ in a ratio of $8: 2$. Furthermore, the acyl groups of the peptides were formulated as $\mathrm{C}_{10} \mathrm{H}_{19} \mathrm{O}_{2}$ and $\mathrm{C}_{11} \mathrm{H}_{21} \mathrm{O}_{2}$, respectively. ${ }^{1} \mathrm{H}$ NMR studies of 1 (COSY and 2D-homonuclear Hartmann-Hahn spectroscopy) confirmed the presence of all aforementioned amino acids ${ }^{2)}$ (Table 3) and $\beta$-hydroxylcarboxylic acid residues $(\delta 0.75 \sim 0.9(\mathrm{Me}), 1.10(\mathrm{~m}), 1.23(\mathrm{br} \mathrm{s}), 1.35(\mathrm{~m}$, $\gamma-\mathrm{H}), 3.80(\mathrm{~m}, \beta-\mathrm{H}), 2.23(\mathrm{dd}, J=8$ and $14 \mathrm{~Hz}, \alpha-\mathrm{H}), 2.30$ (dd, $J=5$ and $14 \mathrm{~Hz}, \alpha-\mathrm{H}$ )). The methyl signals of the complex appeared between $\delta 0.75 \sim 0.9$ and overlapped each other. The presence of anteiso and straight-chain carboxylic acid residues was suggested with $J$-resolved 2D spectrum of 1 (Fig. 2). The spectrum indicated the presence of seven methyl signals in the region: $\delta 0.78(\mathrm{~d}$, Ile), 0.79 (t, Ile), 0.83, 0.84 (each d, Val), 0.82 (t, straight-chain carboxylic acid), 0.85 (d, anteiso carboxylic acid), and 0.86 ( $t$, anteiso carboxylic acid). By a peak height comparison of the triplet signals of the anteiso carboxylic acid and the methyl signal of the isoleucine, the ratio of anteiso carboxylic acid to straight-chain isomer was calculated to be about $4: 1$. The structures of the $\beta$-hydroxylcarboxylic acid residues were confirmed 
Fig. 2. $J$-Resolved 2D spectrum of Bu-2841-08 (1) in DMSO- $d_{6}$.

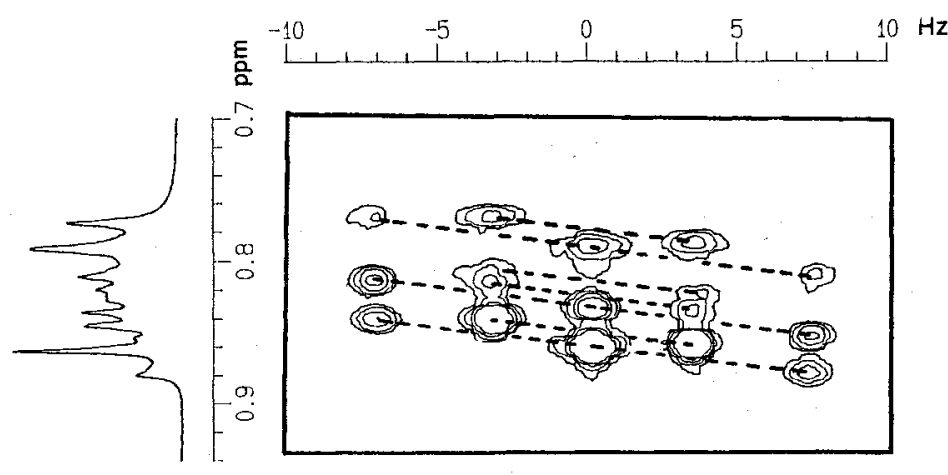

The region between $\delta 0.7 \sim 0.92\left(400 \mathrm{MHz}, 60^{\circ} \mathrm{C}\right)$.

Fig. 3. Fragment ion peaks observed in the positive ion FAB-MS/MS of $(M+H)^{+}$ion of 1 a.
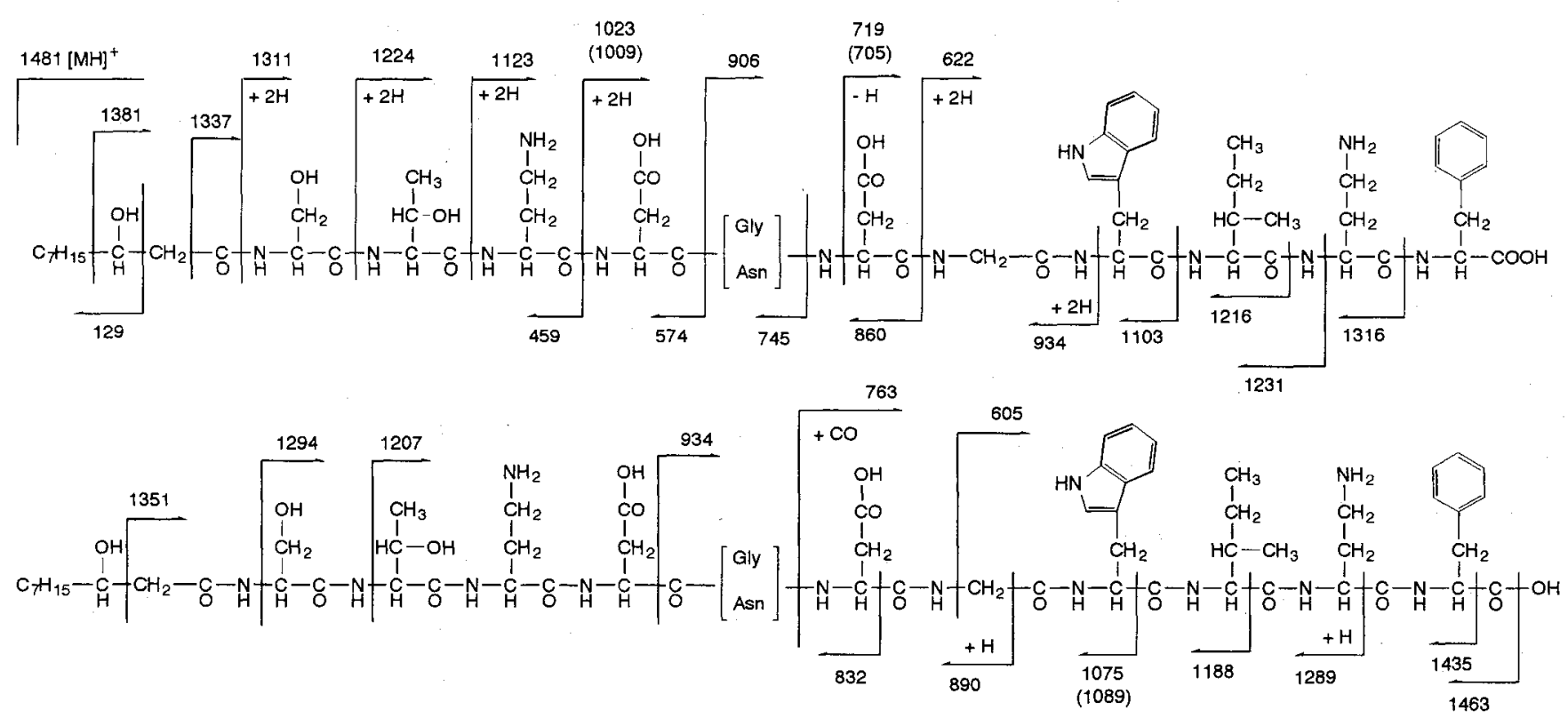

The mass numbers shown in parentheses were fragment ions derived from minor peptide(s) (containing valine residue instead of isoleucine).

with the ${ }^{13} \mathrm{C}$ NMR spectrum: $\beta$-hydroxyanteisodecanoic acid, $\delta 10.6(\mathrm{C} 9, \mathrm{Me}), 21.8$ (C10, Me), 24.7 (C5), 31.0 (C8), 36.0 (C6), 36.7 (C4), 40.4 (C7), 43.2 (C2), 67.5 (C3), and $\beta$-hydroxydecanoic acid, $\delta$ 13.6 (C10), 24.3 (C9), 26.3 (C5), 28.4 (C7), 28.8 (C6), 33.5 (C8), 36.7 (C4), 43.2 $\left.(\mathrm{C} 2), 67.5(\mathrm{C} 3)^{3}\right)$. The minor acyl group $\left(\mathrm{C}_{11}\right)$ was not detected in the spectrum of 1 . On the other hand, the ratio of an anteiso carboxylic acid to straight-chain isomer $\left(\mathrm{C}_{11}\right)$ of $\mathrm{Bu}-2841-10$ (2) was about $4: 1$ as described in next subsection, from which the ratio of the minor carboxylic acid residues $\left(C_{11}\right)$ of 1 may be same as that of main acyl groups of 2 . The presence of an intramolecular ester linkage was found by hydrolysis of 1 with tris-buffer $(\mathrm{pH} 8.5)$ at $40^{\circ} \mathrm{C}$. In the ${ }^{1} \mathrm{H}$ NMR spectrum of the hydrolysate $\left(1 \mathrm{a}, m / z .1481(\mathrm{M}+\mathrm{H})^{+}\right)$, $\beta$-proton signal of threonine $(\delta 4.07(\mathrm{~m}))$ appeared at more upfield than that of $\mathbf{1}$, while those of serine and the acyl group were observed at almost same region of those of 1. No information for the structure was obtained from the FAB-MS of 1 except the molecular weight. Positive ion FAB-MS/MS of quasi-molecular ion $(\mathrm{M}+\mathrm{H})^{+}$of 1 as a precursor ion, however, gave the fragment ions derived from cleavage of the side chain, $m / z 1293\left(\mathrm{MH}-\mathrm{C}_{10} \mathrm{H}_{18} \mathrm{O}_{2}\right)^{+}, 1206\left(\mathrm{MH}-\mathrm{C}_{10} \mathrm{H}_{19} \mathrm{O}_{2}-\right.$ Ser $+\mathrm{H})^{+},\left(1279\left(\mathrm{MH}-\mathrm{C}_{11} \mathrm{H}_{20} \mathrm{O}_{2}\right)^{+}\right.$: minor peptide), etc. ${ }^{4)}$, and also from cleavage between $\alpha$ - and $\beta$-carbons of amino acid residue(s) accompanied by elimination of an amide proton, $m / z 1418\left(\mathrm{MH}-\mathrm{C}_{2} \mathrm{H}_{7} \mathrm{~N}(2,4-\mathrm{Dab})\right)^{+}$, $1403\left(\mathrm{MH}-\mathrm{C}_{2} \mathrm{H}_{4} \mathrm{O}_{2}(\mathrm{Asp})\right)^{+}, 1343\left(\mathrm{MH}-\mathrm{C}_{4} \mathrm{H}_{8} \mathrm{O}_{4}\right.$ $(2 \times \mathrm{Asp}))^{+}$, etc. However, the spectrum did not give any 
Fig. 4. NOE data of $\mathbf{1}$ observed with ROESY spectrum.

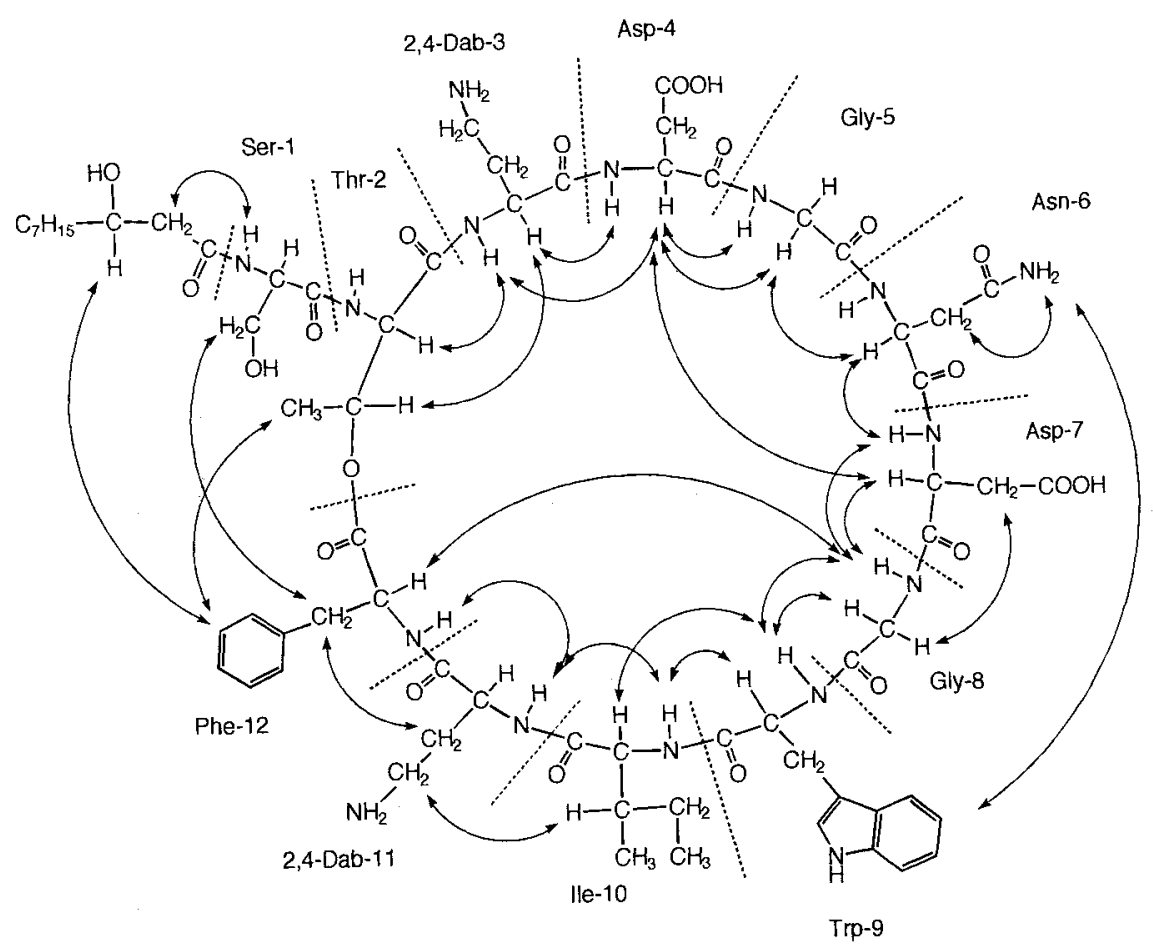

$500 \mathrm{MHz}$, at $60^{\circ} \mathrm{C}$, mixing time: 0.1 second

ion peaks from cleavage of the cyclic peptide chain (cleavages of peptide bond or ester bond and between $\alpha$-carbon and amino or carbonyl group). The above data indicated that the $C$-terminal amino acid is linked by an ester bond to the threonine residue and that the $\gamma$-amino group of 2,4-diaminobutyric acids and the $\gamma$-carbonyl group of aspartic acids did not form a peptide bond. The amino acid sequence of 1a was determined by the positive ion FAB-MS/MS of its quasi-molecular ion $\left((\mathrm{M}+\mathrm{H})^{+}\right)$ except for the sequence of glycine and asparagine (Fig. $3)^{4}$. The fifth and sixth residues were determined with rotating frame NOE spectroscopy (ROESY) spectrum as glycine and asparagine, respectively, as shown in Fig. 4. Thus, the structure of the main component of $\mathrm{Bu}-2841-08$ is as follows:

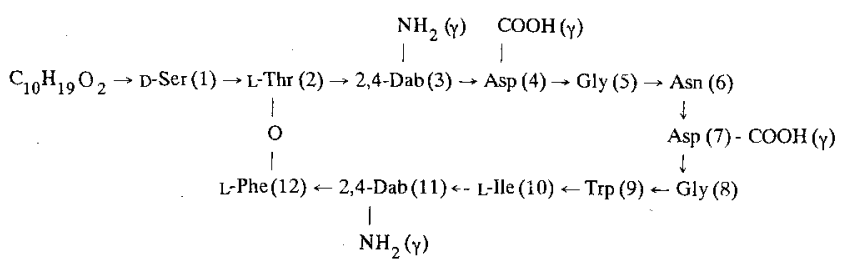

FAB-MS of Bu-2841-10 (2) gave a protonated molecular ion peak at $m / z 1477$; this peak was 14 daltons larger than that of $\mathrm{Bu}-2841-08$ (1). Positive ion FABMS/MS of the quasi-molecular ion $\left((\mathrm{M}+\mathbf{H})^{+}\right)$of 2 gave fragment ions at $m / z 1293\left(\mathrm{MH}-\mathrm{C}_{11} \mathrm{H}_{20} \mathrm{O}_{2}\right)^{+}$and 1206 $\left(\mathrm{MH}-\mathrm{C}_{11} \mathrm{H}_{21} \mathrm{O}_{2}-\mathrm{Ser}+\mathrm{H}\right)^{+}$. Amino acid analysis of 2 gave the same result as 1 except a ratio of isoleucine ( 0.9 eq.) to valine ( 0.1 eq.). In ${ }^{1} \mathrm{H}$ NMR spectrum of 2 , the chemical shifts and coupling patterns of the amino acid residues were similar to those of $\mathbf{1}$ (Table 3). These data suggested that the structure of cyclic peptide moiety is identical with that of $\mathbf{1}$, and the sequence of amino acids and acyl group was confirmed with NOESY spectrum of 2 . The structures of acyl groups $\left(\mathrm{C}_{11} \mathrm{H}_{21} \mathrm{O}_{2}\right)$ were determined by $J$-resolved $2 \mathrm{D}$ spectrum as 3hydroxy-8-methyldecanoic acid and 3-hydroxyundecanoic acid (the ratio was about $4: 1$ ). In the ${ }^{13} \mathrm{C}$ NMR spectrum of 2, the carbon signals of 3-hydroxy8-methyldecanoic acid moiety were observed at $\delta 10.6$ (C10, Me), 18.9 (C11, Me), 26.4 (C5), 28.7 (C6), 33.5 (C9), 35.8 (C7), 36.8 (C4), 42.4 (C8), 43.2 (C2), 67.5 (C3), but those of 3-hydroxyundecanoic moiety were not detected. From these data, 2 was determined to have the same core peptide as $\mathbf{1}$ but different acyl groups.

The stereochemistry of amino acid residues (residue-3, $-4,-6,-7,-9$, and -11 ) was determined by the NOE data 
Table 3. ${ }^{1} \mathrm{H}$ and ${ }^{13} \mathrm{C}$ NMR spectral data ${ }^{\mathrm{a}}$ of amino acid residues of Bu-2841-08 (1) and -10 (2) in DMSO- $d_{6}$ at $60^{\circ} \mathrm{C}(500 \mathrm{MHz})$.

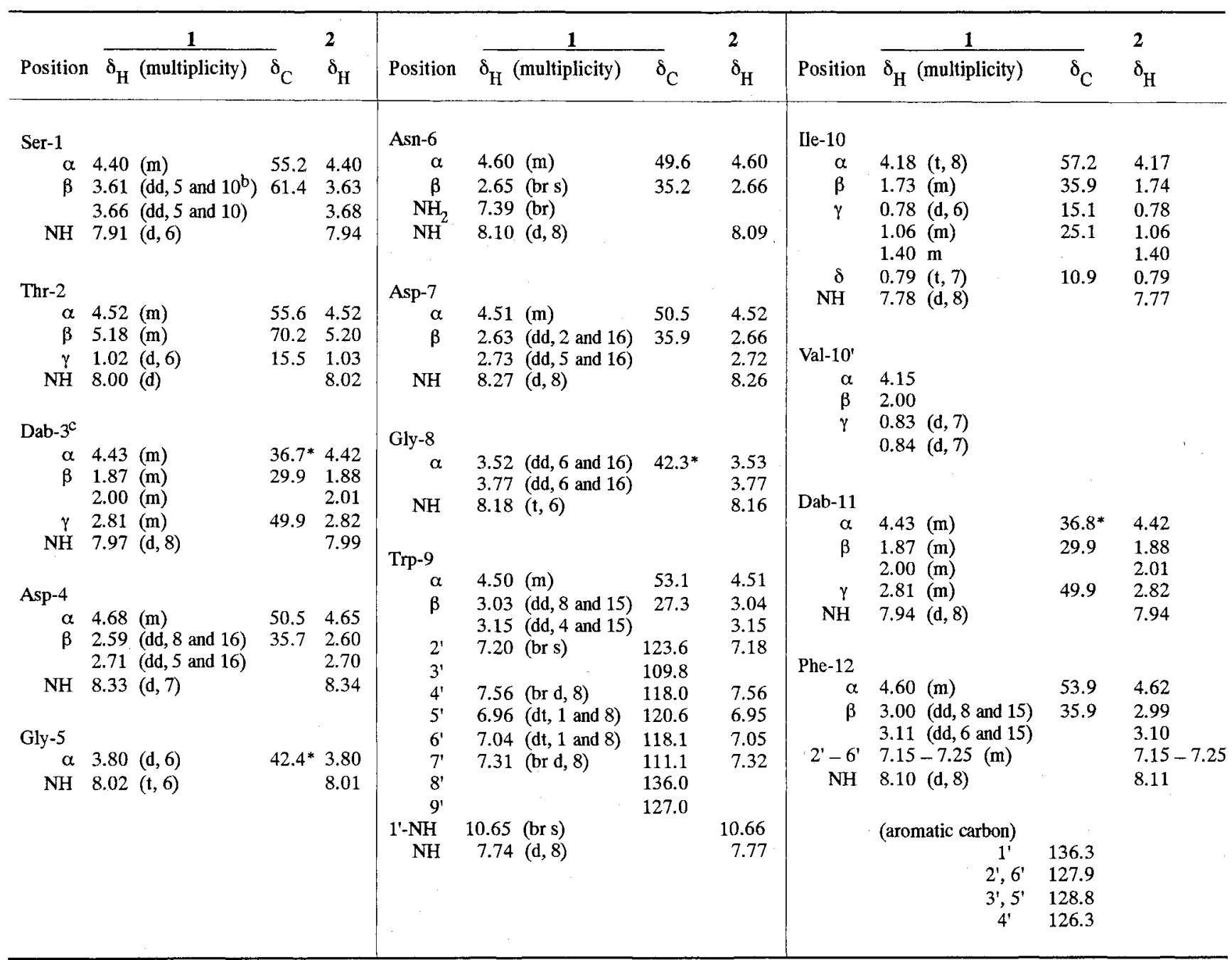

a Carbonyl groups: $\delta 168.6,168.7,168.8,170.1,170.6,170.7,170.8,171.1,171.3(2 \mathrm{C}), 171.4,171.5(3 \mathrm{C}), 171.8$.

b Coupling constants in $\mathrm{Hz}$.

c 2,4-diaminobutyric acid.

* The assignments may be exchanged with corresponding carbons of same amino acid residue.

(Fig. 5) and an examination of molecular models considered from observed intramolecular hydrogenbonds. The hydrogen-bonds were found for the amide NH protons of 2,4-diaminobutyric acid-3 and tryptophan-9 with ${ }^{1} \mathrm{H}$ NMR measurements of 2 at various temperatures (Table 4$)^{5)}$. By comparison of the spectra measured at $40^{\circ} \mathrm{C}$ and $60^{\circ} \mathrm{C}$, the shifts of these amide NH protons were negligible $(0 \sim 0.03 \mathrm{ppm})$, while those of other amide $\mathrm{NH}$ protons were $0.08 \sim 0.13 \mathrm{ppm}$. On the other hand, NOEs were observed between the amide NH proton of aspartic acid- 4 and $\alpha$-proton of the other aspartic acid-7 and between the $\alpha$-protons of glycine- 8 and phenylalanine- 12 in the NOESY spectrum of 2 (Fig. 5). These data indicated that the hydrogen-bonds exist between the amide $\mathrm{NH}$ proton of 2,4-diaminobutyric acid-3 and the carbonyl oxygen of aspartic acid- 7 and between the amide $\mathrm{NH}$ proton of tryptophan -9 and the carbonyl oxygen of 2,4-diaminobutyric acid-11. NOE was also observed between the $\beta$-proton of L-isoleucine10 and $\beta$-protons ( $\delta 1.87$ ) of 2,4-diaminobutyric acid-11. A nearest distance between these $\beta$-protons is calculated to be $3.4 \AA$ when the 2,4-diaminobutyric acid- 11 is $\mathrm{L}$-form and $6.1 \AA$ when it is D-form in the molecular models. Therefore, 2,4-diaminobutyric acid-11 was determined as L-form, and consequently the other 2,4-diaminobutyric acid-3 is D-form. The assignment was confirmed by the NOE observed between the $\alpha$-proton of $2,4-$ diaminobutyric acid-3 and the $\beta$-proton of L-phenylalanine-12 (nearest distance between the protons of $L$ phenylalanine-12 and $\mathrm{D}-2,4$-diaminobutyric acid-3 is $1.9 \AA$, and that between L-phenylalanine- 12 and L-2,4diaminobutyric acid-3 is $4.8 \AA$ ). The NOE between 
Fig. 5. NOE data of 2 observed with NOESY spectrum.

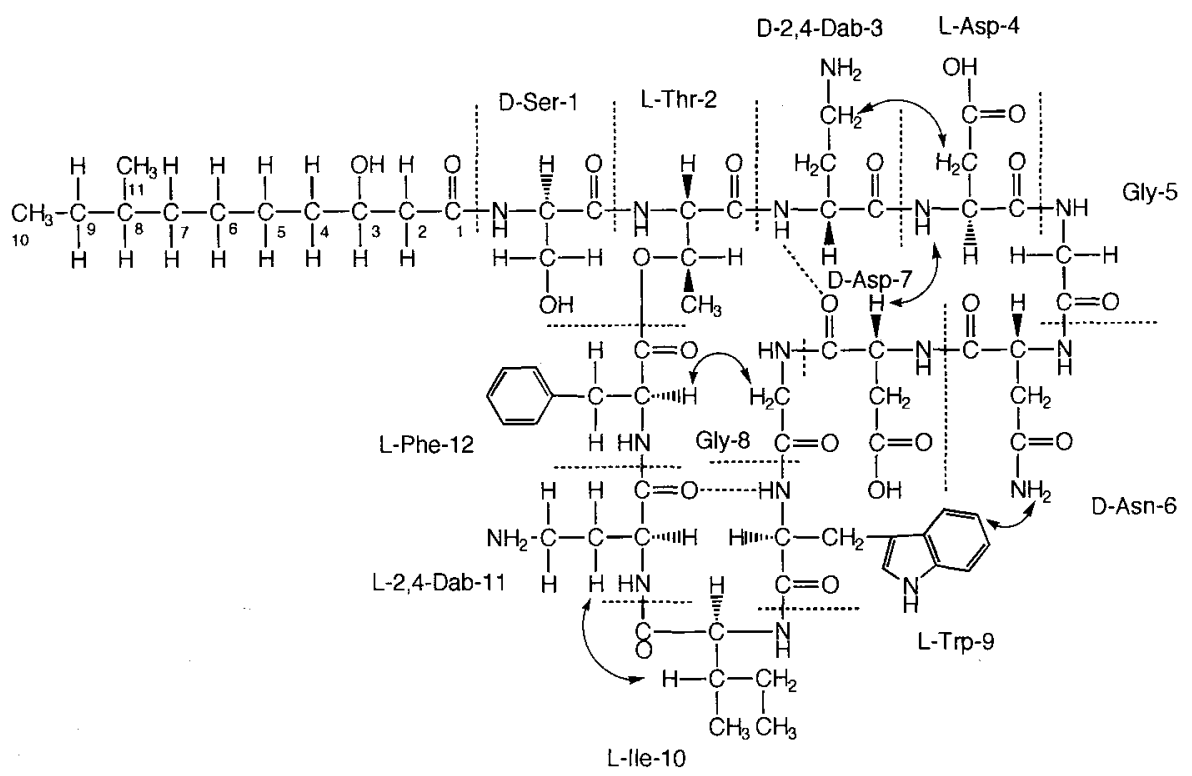

$400 \mathrm{MHz}$, at $60^{\circ} \mathrm{C}$, mixing time: 0.4 second.

Table 4. Chemical shifts of amide protons of Bu-2841-10 (2) in DMSO- $d_{6}$ at 40,50 , and $60^{\circ} \mathrm{C}(400 \mathrm{MHz}){ }^{\mathrm{a}}$

\begin{tabular}{l|cccc}
\hline Temperature & $40^{\circ} \mathrm{C}$ & $50^{\circ} \mathrm{C}$ & $60^{\circ} \mathrm{C}$ & $\Delta\left(40^{\circ} \mathrm{C}-60^{\circ} \mathrm{C}\right)$ \\
\hline Ser-1 & 8.03 & 7.98 & 7.94 & 0.09 \\
Thr-2 & 8.13 & 8.07 & 8.02 & 0.11 \\
Dab-3 & 8.02 & 8.00 & 7.99 & 0.03 \\
Asp-4 & 8.44 & 8.38 & 8.34 & 0.10 \\
Gly-5 & 8.10 & 8.05 & 8.01 & 0.09 \\
Asn-6 & 8.17 & 8.13 & 8.09 & 0.08 \\
Asp-7 & 8.36 & 8.31 & 8.26 & 0.10 \\
Gly-8 & 8.26 & 8.21 & 8.16 & 0.10 \\
Trp-9 & 7.77 & 7.76 & 7.77 & 0.00 \\
(1'-NH) & $(10.78)$ & $(10.68)$ & $(10.61)$ & $(0.17)$ \\
Ile-10 & 7.90 & 7.84 & 7.77 & 0.13 \\
Dab-11 & 8.02 & 7.99 & 7.94 & 0.08 \\
Phe-12 & 8.19 & 8.15 & 8.11 & 0.08 \\
& & & & \\
\hline
\end{tabular}

${ }^{a}$ These protons were assigned with COSY spectra.

$\gamma$-proton(s) of D-2,4-diaminobutyric acid-3 and the $\beta$-proton of aspartic acid-4 $(\delta 2.59)$ was also observed. The nearest distance between the two protons is $2.6 \AA$ (the residue- 4 is L-form) and $3.8 \AA$ (the residue- 4 is D-form). Therefore, the residue -4 is L-aspartic acid and consequently the other aspartic acid-7 and asparagine- 6 are $\mathrm{D}$-forms. The observed NOE between an aromatic proton of tryptophan residue $\left(\mathrm{C}-5^{\prime}-\mathrm{H}\right)$ and the $\gamma$-amide
$\mathrm{NH}_{2}$ protons of the D-asparagine- 6 indicated that tryptophan-9 is L-form (the nearest distance between these protons is $1.5 \AA$ (D-asparagine- 6 and L-tryptophan9) and $10.2 \AA$ (D-asparagine- 6 and D-tryptophan-9)). To summarize these data, the structure of Bu-2841-08 (1) and -10 (2) were determined as shown in Fig. 6.

Previously, SHолI and KATO reported the structure of brevistin (3) ${ }^{6}$, a cyclic depsipeptide. The structure closely resembled those of the Bu-2841-08 (1) and -10 (2) reported here. However, significant differences reside in the amino acid contents and the acyl groups of brevistin and $\mathrm{Bu}-2841 \mathrm{~s}$.

\section{Antimicrobial Activity}

MICs of the antibiotics were determined by means of a two-fold serial agar dilution method in Mueller-Hinton media for the bacteria, in Sabouraud media for fungi, and in yeast morphology media for yeast. The antibacterial and antifungal spectra are given in Table 5 . These antibiotics are similarly active against Grampositive bacteria, but practically inactive against Gramnegative bacteria and fungi.

\section{Experimental}

Instruments

FAB-MS and FAB-MS/MS spectra were obtained with a Jeol JMS-SX102/102A tandem mass spectrometer. Xenon was used to provide the preliminary beam of atoms $(5 \mathrm{Kw})$. The liquid matrix used for FAB ionization was 3-nitrobenzyl alcohol. MS/MS spectra were obtained 
Fig. 6. Structures of Bu-2841-08 (1), -10 (2), and brevistin (3).

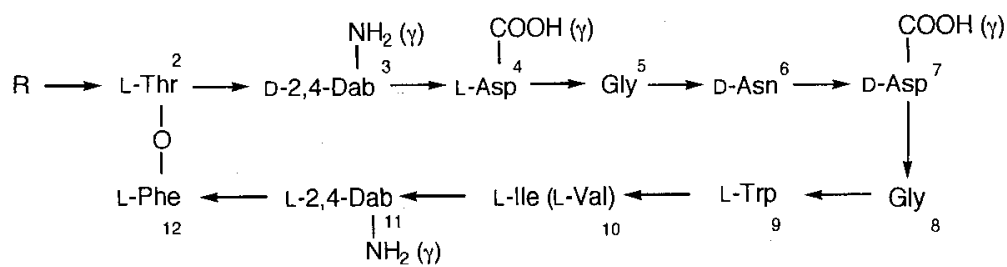

$$
\begin{aligned}
& \text { 1: } \mathrm{R}=\mathrm{CH}_{3} \mathrm{CH}_{2} \mathrm{CH}\left(\mathrm{CH}_{3}\right)\left(\mathrm{CH}_{2}\right)_{3} \mathrm{CH}(\mathrm{OH}) \mathrm{CH}_{2} \mathrm{CO} \longrightarrow \mathrm{D}-\mathrm{Ser} \text { - } \\
& \mathrm{CH}_{3}\left(\mathrm{CH}_{2}\right)_{6} \mathrm{CH}(\mathrm{OH}) \mathrm{CH}_{2} \mathrm{CO} \rightarrow \mathrm{D}-\mathrm{Ser} \text { - } \\
& \left(\begin{array}{l}
\mathrm{CH}_{3} \mathrm{CH}_{2} \mathrm{CH}\left(\mathrm{CH}_{3}\right)\left(\mathrm{CH}_{2}\right)_{4} \mathrm{CH}(\mathrm{OH}) \mathrm{CH}_{2} \mathrm{CO} \longrightarrow \mathrm{D}^{2} \mathrm{Ser}^{1}-\text {, and } / \text { or } \\
\mathrm{CH}_{3}\left(\mathrm{CH}_{2}\right)_{7} \mathrm{CH}(\mathrm{OH}) \mathrm{CH}_{2} \mathrm{CO} \longrightarrow \text {-Ser }-
\end{array}\right) \\
& \text { 2: } \mathrm{R}=\mathrm{CH}_{3} \mathrm{CH}_{2} \mathrm{CH}\left(\mathrm{CH}_{3}\right)\left(\mathrm{CH}_{2}\right)_{4} \mathrm{CH}(\mathrm{OH}) \mathrm{CH}_{2} \mathrm{CO} \longrightarrow \mathrm{D}-\mathrm{Ser}-\text {, } \\
& \mathrm{CH}_{3}\left(\mathrm{CH}_{2}\right)_{7} \mathrm{CH}(\mathrm{OH}) \mathrm{CH}_{2} \mathrm{CO} \rightarrow \text { D-Ser', } \\
& \left(\begin{array}{l}
\mathrm{CH}_{3} \mathrm{CH}_{2} \mathrm{CH}\left(\mathrm{CH}_{3}\right)\left(\mathrm{CH}_{2}\right)_{5} \mathrm{CH}(\mathrm{OH}) \mathrm{CH}_{2} \mathrm{CO} \longrightarrow \mathrm{D}-\mathrm{Ser}-\text {, and } / \mathrm{or} \\
\mathrm{CH}_{3}\left(\mathrm{CH}_{2}\right)_{8} \mathrm{CH}(\mathrm{OH}) \mathrm{CH}_{2} \mathrm{CO} \longrightarrow \mathrm{D}-\mathrm{Ser}-
\end{array}\right)
\end{aligned}
$$

3: $\mathrm{R}=\mathrm{CH}_{3} \mathrm{CH}_{2} \mathrm{CH}\left(\mathrm{CH}_{3}\right)\left(\mathrm{CH}_{2}\right)_{4} \mathrm{CO}-$

by activating the ions in the third field free region by collision with argon gas. GC-MS was recorded on a Shimadzu LKB-9000 apparatus using an OV-17 column with temperature programing of $5^{\circ} \mathrm{C} /$ minute from $100^{\circ} \mathrm{C}$. NMR spectra were recorded on a Jeol JNM-EX400 $\left(400 \mathrm{MHz}\right.$ for ${ }^{1} \mathrm{H}$ and $100 \mathrm{MHz}$ for ${ }^{13} \mathrm{C}$ ) or a Jeol JNM- $\alpha-500\left(500 \mathrm{MHz}\right.$ for ${ }^{1} \mathrm{H}$ and $125 \mathrm{MHz}$ for $\left.{ }^{13} \mathrm{C}\right)$ spectrometer. As ${ }^{1} \mathrm{H}$ NMR chemical shift reference, the center signal of DMSO- $d_{6}$ at $\delta 2.50$, and as ${ }^{13} \mathrm{C}$ NMR reference, the methyl signal of DMSO- $d_{6}$ at $\delta 39.5 \mathrm{ppm}$ were used. Amino acid analyses were performed with a Hitachi amino acid autoanalyzer model L-8500. UV spectra were recorded on a Shimadzu UV-265 spectrophotometer. Optical rotations were determined with a Jasco model DIP 140. For the examination with molecular models, Maruzen Biochemistry Molecular Model (peptide model) was used.

\section{Acid Hydrolysis of Antibiotics}

A solution of $\mathrm{Bu}-2841$ complex $(1.2 \mathrm{mg})$ in $0.5 \mathrm{ml}$ of $6 \mathrm{~N} \mathrm{HCl}$ was heated at $110^{\circ} \mathrm{C}$ for 24 hours in a vacuumsealed tube. The hydrolysate, after concentration to dryness in vacuo on a water-bath at $60^{\circ} \mathrm{C}$, was dissolved in $0.02 \mathrm{~N} \mathrm{HCl}$ to $1.2 \mathrm{ml}$ and $10 \mu$ lo the solution was analyzed with the amino acid analyzer (Table 1).

A mixture of each isolated peptides $(0.2 \sim 0.6 \mathrm{mg}), 6 \mathrm{~N}$ $\mathrm{HCl}(0.5 \mathrm{ml})$, and thioglycolic acid $(50 \mu \mathrm{l})$ was heated at $110^{\circ} \mathrm{C}$ for 24 hours in a vacuum-sealed tube. The hydrolysate, after treatment of the usual manner, was analyzed with the amino acid analyzer. The results were given in Table 2.

In order to determine the constituent fatty acids and the chirality of amino acids, a mixture of Bu-2841
Table 5. Antibacterial and antifungal spectra of $\mathrm{Bu}-2841-08$ (1) and -10 (2).

\begin{tabular}{lcc}
\hline \multirow{2}{*}{ Organisms tested } & \multicolumn{2}{c}{ MIC $(\mu \mathrm{g} / \mathrm{ml})$} \\
\cline { 2 - 3 } & $\mathrm{Bu}-2841-08$ & $\mathrm{Bu}-2841-10$ \\
\hline Bacillus cereus IFM 2058 & 25 & 50 \\
B. megaterium IFM 2059 & 50 & 50 \\
B. subtilis PCI 219 IFM 2060 & 25 & 25 \\
Corynebacterium diphtheriae IFM 2056 & 12.5 & 25 \\
C. xerosis IFM 2057 & 3.13 & 1.56 \\
Micrococcus luteus IFM 2066 & 6.25 & 6.25 \\
Mycobacterium smegmatis IFM 2051 & 100 & 100 \\
Staphylococcus aureus FDA 209P IFM 2014 & 1.56 & 0.78 \\
S. aureus IFM 2013 & 12.5 & 25 \\
S. aureus IFM 2018 & 25 & 25 \\
Streptococcus faecalis IFM 2001 & 25 & 25 \\
S. salivarius IFM 2010 & 25 & 25 \\
Escherichia coli IFM 3002 & $>100$ & $>100$ \\
Pseudomonas aeruginosa IFM 3011 & $>100$ & $>100$ \\
Aspergillus fumigatus IFM 25 & $>100$ & $>100$ \\
Penicillium expansum IFM 40619 & $>100$ & $>100$ \\
Trichophyton mentagrophytes IFM 40734 & $>100.00$ & $>100$ \\
Candida albicans IFM 40009 & $>100.00$ & $>100$ \\
Cryptococcus neoformans IFM 40038 & $>100.00$ & $>100$ \\
\hline
\end{tabular}

complex $(1.0 \mathrm{~g}), 6 \mathrm{~N} \mathrm{HCl}(42 \mathrm{ml})$, and thioglycolic acid $(1.8 \mathrm{ml})$ was heated at $110^{\circ} \mathrm{C}$ for 17 hours in a vacuumsealed tube. The reaction mixture was extracted with ethyl ether. Evaporation of the ether extract afforded an oily residue. The aqueous layer was concentrated in vacuo to a residue which was chromatographed on a column of Dowex $50 \mathrm{~W} \times 4\left(\mathrm{H}^{+}\right.$form, $\left.2 \times 52 \mathrm{~cm}\right)$ de- 
veloping with an increasing concentration of $\mathrm{HCl}(0.05$ $2.0 \mathrm{~N})$. Appropriate fractions (Asp (120 mg); eluted with $\mathrm{H}_{2} \mathrm{O}$, Asp, Ser, Thr $(331 \mathrm{mg}$ ) with $0.2 \mathrm{~N} \mathrm{HCl}$, Val $(24 \mathrm{mg})$ with $0.3 \mathrm{~N} \mathrm{HCl}$, Ile $(77 \mathrm{mg}$ ) with $0.4 \mathrm{~N} \mathrm{HCl}$, Phe $(137 \mathrm{mg})$ with $0.5 \mathrm{~N} \mathrm{HCl}, 2,4-\mathrm{Dab}(229 \mathrm{mg})$ with $0.7 \mathrm{~N} \mathrm{HCl})$ ) were pooled and concentrated under reduced pressure. The amino acids were further purified with column chromatography on Amberlite IRA-400 ( $\mathrm{Cl}^{-}$form) and XAD-2, eluted with $\mathrm{H}_{2} \mathrm{O}$, to give aspartic acid (203 mg), glycine $(115 \mathrm{mg})$, valine $(22 \mathrm{mg})$, isoleucine $(72 \mathrm{mg})$, phenylalanine $(117 \mathrm{mg})$, and 2,4-diaminobutyric acid $(218 \mathrm{mg})$ as hydrochlorides. Threonine hydrochloride $(72 \mathrm{mg})$ and serine hydrochloride $(52 \mathrm{mg})$ were isolated by preparative TLC (Avicel, developer; $\mathrm{BuOH}-\mathrm{AcOH}-\mathrm{H}_{2} \mathrm{O}(8: 1: 1)$ ) and column chromatography on Amberlite IRA-400 $\left(\mathrm{Cl}^{-}\right.$form, $\left.\mathrm{H}_{2} \mathrm{O}\right)$. A part of the oily residue obtained from the above ethereal extract was treated with diazomethane in ethereal solution. After evaporation of the solvent, the residue was analyzed by the GC-MS spectrometer.

\section{$\mathrm{Bu}-2842-08$ (1)}

Bu-2841-08 (1) was obtained as a colorless powder. HRFAB-MS: $m / z 1463.7170(\mathrm{M}+\mathrm{H})^{+}, \Delta-0.1 \mathrm{mmu}$ for $\mathrm{C}_{67} \mathrm{H}_{99} \mathrm{O}_{21} \mathrm{~N}_{16}$. Positive ion FAB-MS: $m / z 1523$ $(\mathrm{M}-\mathrm{H}+\mathrm{Na}+\mathrm{K})^{+}, 1501(\mathrm{M}+\mathrm{K})^{+}, 1485(\mathrm{M}+\mathrm{Na})^{+}$, $1463(\mathrm{M}+\mathrm{H})^{+}, 732(\mathrm{M}+2 \mathrm{H})^{2+} / 2$. Negative ion FAB-MS: $m / z 1461(\mathrm{M}-\mathrm{H})^{-}$. Positive ion FAB-MS/MS of $(\mathrm{M}+\mathrm{K})^{+}$at $m / z 1501 ; m / z 1483,1456,1443,1441$, 1411, 1383, 1372, 1371, 1331, 1315, 1272. Positive ion FAB-MS/MS of $(\mathrm{M}+\mathrm{Na})^{+}$at $\mathrm{m} / z$ 1485: $\mathrm{m} / z$ 1467, 1455 , 1441, 1427, 1368, 1367, 1355, 1315, 1228, 129. Positive ion FAB-MS/MS of $(\mathrm{M}+\mathrm{H})^{+}$at $m / z$ 1463: $m / z$ 1445, $1433,1419,1418\left(\mathrm{MH}-\mathrm{C}_{2} \mathrm{H}_{7} \mathrm{~N}\right.$ (cleavage between $\alpha$ and $\beta$-bond of 2,4-Dab) $)^{+}, 1405\left(\mathrm{MH}-\mathrm{C}_{4} \mathrm{H}_{10}(\mathrm{Ile})\right)^{+}$, $1404\left(\mathrm{MH}-\mathrm{C}_{2} \mathrm{H}_{5} \mathrm{ON}(\text { Asn })\right)^{+}, 1403\left(\mathrm{MH}-\mathrm{C}_{2} \mathrm{H}_{4} \mathrm{O}_{2}\right.$ $(\mathrm{Asp}))^{+}, 1372\left(\mathrm{MH}-\mathrm{C}_{7} \mathrm{H}_{7}(\mathrm{Phe})\right)^{+}, 1345\left(\mathrm{MH}-\mathrm{C}_{4} \mathrm{H}_{10}\right.$ (Ile) $-\mathrm{C}_{2} \mathrm{H}_{4} \mathrm{O}_{2}$ (Asp)) ${ }^{+}, 1344\left[\mathrm{MH}-\mathrm{C}_{2} \mathrm{H}_{4} \mathrm{O}_{2}\right.$ (Asp)$\left.\mathrm{C}_{2} \mathrm{H}_{5} \mathrm{ON}(\mathrm{Asn})\right)^{+}, 1343\left(\mathrm{MH}-2 \mathrm{C}_{2} \mathrm{H}_{4} \mathrm{O}_{2}(2 \mathrm{Asp})\right)^{+}, 1332$ $\left.\left(\mathrm{MH}-\mathrm{C}_{9} \mathrm{H}_{9} \mathrm{~N}\right)\right)^{+}, 1319,1293,1279,1276,1233,1206$. Negative ion FAB-MS/MS of $(\mathrm{M}-\mathrm{H})^{-}$at $m / z$ 1461: $m / z$ $1445,1443,1332,1275,700$.

\section{Bu-2841-10 (2)}

$\mathrm{Bu}-2841-10$ (2) was obtained as a colorless powder. Positive ion FAB-MS: $m / z 1537(\mathrm{M}-\mathrm{H}+\mathrm{Na}+\mathrm{K})^{+}$, $1515(\mathrm{M}+\mathrm{K})^{+}, 1499(\mathrm{M}+\mathrm{Na})^{+}, 1477(\mathrm{M}+\mathrm{H})^{+}$, $(\mathrm{M}+2 \mathrm{H})^{2+} / 2$. Negative ion FAB-MS: $m / z \quad 1475$ $(\mathrm{M}-\mathrm{H})^{-}, 700$. Positive ion FAB-MS/MS of $(\mathrm{M}+\mathrm{H})^{+}$ at $m / z$ 1477: $m / z \quad 1459,1447,1433,1432,1419,1418$, $2386,2359,1358,1293,1276,1262,1234,1206,1189$, 272, 143. Positive ion FAB-MS/MS of $(\mathrm{M}+\mathrm{Na})^{+}$at $m / z$ 1499: $m / z 1481,1469,1455,1441,1440,1439,1398,1368$, 1315. Positive ion FAB-MS/MS of (M+K) ${ }^{+}$at $m / z$ 1515: $m / z$ 1497, 1485, 1471, 1456, 1386, 1331, 1329, 1286. Negative ion FAB-MS/MS of $(\mathrm{M}-\mathrm{H})^{-}$at $m / z$ 1476: $m / z$ $1457,1346,1232,700 .{ }^{13} \mathrm{C}$ NMR $\left(100 \mathrm{MHz}\right.$, DMSO- $\left.d_{6}\right)$ : amino acid, Ser $\delta$ 55.3, 61.4; $\operatorname{Thr} \delta$ 15.6, 55.7, 70.2;
2,4-Dab $\delta 29.5,29.9,36.1$ (2C), 49.9, 50.0; Asp $\delta 36.3$, $35.8,50.5$ (2C); Gly $\delta 42.4,42.5$; Asn $\delta 36.0,49.7$; Trp $\delta$ 26.7, 54.1, 109.8, 111.1, 118.1, 120.7, 127.1, 123.6, 136.0; Ile $\delta 10.9,15.1,25.1,36.0,57.3$; Phe $\delta 36.1,53.7,126.4$, $128.0,128.9,136.4$, carbonyl carbons $\delta 168.8,168.9$, $169.0,169.8,170.3,170.8,170.9(2 \mathrm{C}), 171.2(2 \mathrm{C}), 171.3$, 171.6, $171.7(2 \mathrm{C}), 171.8(2 \mathrm{C})$.

\section{Mild Alkaline Hydrolysis of Bu-2841-08 (1)}

A mixture of Bu-2841-08 (5 mg), acetonitrile $(3 \mathrm{ml})$, $\mathrm{H}_{2} \mathrm{O}(1 \mathrm{ml})$, and $0.2 \mathrm{M}$ tris- $\mathrm{HCl}$ buffer $(\mathrm{pH} 8.5,5 \mathrm{ml})$ was kept at $40^{\circ} \mathrm{C}$ for 17 hours. The reaction mixture was subjected on a ODS column and eluted sequentially with $\mathrm{H}_{2} \mathrm{O}$ and $\mathrm{MeOH}$. The $\mathrm{MeOH}$ eluate, after evaporated under reduced pressure, was purified by reversed phase HPLC (column; Senshu-Pak ODS-4251-W, $10 \times 250 \mathrm{~mm}$, mobile phase; iso-PrOH - acetonitrile $-0.1 \%$ TFA ( $3: 1$ : 6), flow rate; $1 \mathrm{ml} /$ minute, detection: $U V 230 \mathrm{~nm}$ ) to yield 1a $(1 \mathrm{mg})$ as a colorless powder. Positive ion FAB-MS: $m / z 1522(\mathrm{M}+\mathrm{K})^{+}, 1503(\mathrm{M}+\mathrm{Na})^{+}, 1481(\mathrm{M}+\mathrm{H})^{+}$, $1463,1435,1075,934,741(\mathrm{M}+2 \mathrm{H})^{2+} / 2$. Negative ion FAB-MS: $m / z \quad 1501(\mathrm{M}+\mathrm{Na}-2 \mathrm{H})^{-}, 1479(\mathrm{M}-\mathrm{H})^{-}$, 1021, 1461, 858, 647, 572. Positive ion FAB-MS/MS of $(\mathrm{M}+\mathrm{Na})^{+}$at $m / z$ 1503: $m / z$ 1485, 1473, 1459, 1338, $1210,1186,1079,1045,882,624,496$. Negative ion FAB-MS/MS of $(\mathrm{M}-\mathrm{H})^{-}$at $m / z$ 1479: $m / z 1461,1449$, $1435,1314,1214,801,700,358.185$. Positive ion FABMS/MS of ion at $m / z 1075: m / z 1057,817,889,860,832$, $745,717,617,547,546,488$. Positive ion FAB-MS/MS of ion at $m / z$ 934: $m / z 917,916,890,860,778,576,566$, $460,371 .{ }^{1} \mathrm{H}$ NMR $\left(400 \mathrm{MHz}, \mathrm{DMSO}-d_{6}, 60^{\circ} \mathrm{C}\right)$ : amino acid, Ser $\delta 3.62(2 \mathrm{H}, \mathrm{m}), 4.32(1 \mathrm{H}, \mathrm{m}), 7.99(\mathrm{br}) ; \mathrm{Thr} \delta$ $1.60(3 \mathrm{H}, \mathrm{d}, J=6 \mathrm{~Hz}), 4.07,4.15$ (each $1 \mathrm{H}, \mathrm{m}), 7.72(\mathrm{~d}$, $J=9 \mathrm{~Hz}$ ), 2,4-Dab 1.87, 2.00 (each 2H, m), $2.82(4 \mathrm{H}, \mathrm{m})$, $4.43(2 \mathrm{H}, \mathrm{m}), 7.97$ (br), 8.00 (br); Asp $\delta 2.51,2.58,2.64$, 2.69 (each $1 \mathrm{H}, \mathrm{m}), 4.58(2 \mathrm{H}, \mathrm{m}) ; 8.10$ (br); Gly $\delta 3.37$, 3.60 (each $2 \mathrm{H}, \mathrm{m}), 8.09$ (br); Asn $\delta 2.60(2 \mathrm{H}, \mathrm{m}), 4.52$ $(1 \mathrm{H}, \mathrm{m}), 8.15$ (br); $\operatorname{Trp} \delta 3.08,3.15$ (each $1 \mathrm{H}, \mathrm{dd}, J=5$ and $14 \mathrm{~Hz}), 4.50(1 \mathrm{H}, \mathrm{m}), 6.97,7.05(1 \mathrm{H}, \mathrm{dt}, J=1$ and $8 \mathrm{~Hz}$ ), $7.17(1 \mathrm{H}$, br s), 7.32, 7.57 (each $1 \mathrm{H}$, br d, $J=8 \mathrm{~Hz}$ ), $7.88(\mathrm{br}), 10.68(1 \mathrm{H}, \mathrm{brs})$; Ile $\delta 0.78(2.7 \mathrm{H}, \mathrm{d}, J=6 \mathrm{~Hz})$, $0.80(2.7 \mathrm{H}, \mathrm{t}, J=7 \mathrm{~Hz}), 1.10,1.39,1.75,4.18($ each $0.9 \mathrm{H}$, $\mathrm{m}), 7.76(\mathrm{~d}, J=8 \mathrm{~Hz})$; Phe $\delta 3.00(1 \mathrm{H}$, dd, $J=8$ and $14 \mathrm{~Hz}), 3.15(1 \mathrm{H}, \mathrm{dd}, J=4$ and $14 \mathrm{~Hz}), 4.52(1 \mathrm{H}, \mathrm{m}), 7.88$ (br); acyl group $\delta 0.83(c a .0 .5 \mathrm{H}, \mathrm{d}, J=7 \mathrm{~Hz}), 0.85(c a$. $2.5 \mathrm{H}, \mathrm{d}, J=7 \mathrm{~Hz}), 0.86(c a .2 .5 \mathrm{H}, \mathrm{t}, J=7 \mathrm{~Hz}), 1.25(c a$. $9 \mathrm{H}, \mathrm{br}), 1.37(2 \mathrm{H}, \mathrm{m}), 2.27(2 \mathrm{H}, \mathrm{brd}, J=7 \mathrm{~Hz}), 3.80(1 \mathrm{H}$, $\mathrm{m})$, the amide protons were observed as broad signals. These signals were assigned by the NOESY spectrum.

\section{References}

1) Sugawara, K.; K. Numata, M. Konishi \& H. KawaguCHI: Empedopeptin (BMY-28117), a new depsipeptide antibiotic II. Structure determination. J. Antibiotics 37: 958 964, 1984

2) Rattle, H. W. E.: NMR of amino acids, peptides, and proteins (1977 1979). Annual Reports on NMR Spectroscopy $11 \mathrm{~A}$. Ed. G. A. WebB. pp. $1 \sim 18$. Academic 
Press, London, 1981

3) Isogai, A.; S. Takayama, S. Murakoshi \& A. Suzuki: Structures of $\beta$-amino acids in antibiotics iturin $\mathrm{A}$. Tetrahedron Lett. 23: 3065 3068, 1982

4) Johnson, R. S.; S. A. MARTin \& K. BiemanN: Collision-induced fragmentation of $(\mathrm{M}+\mathrm{H})^{+}$ions of peptides. Side chain specific sequence ions. Int. J. Mass Spectrom. Ion Processes 86: 137 154, 1988
5) OHNISHI, M. \& D. W. URRY: Temperature dependence of amide proton chemical shifts: The secondary structures of gramicidin S and valinomycin. Biochem. Biophys. Res. Commun. 36: 194 202, 1969

6) ShoлI, J. \& T. Kato: The structure of brevistin (Studies on antibiotics from the genus Bacillus. X). J. Antibiotics 29: $380 \sim 389,1976$ 